\title{
Landscape variables influencing forest fires in central Spain
}

\author{
José M. Moreno ${ }^{\mathrm{A}, \mathrm{B}, \mathrm{C}}$, Olga Viedma ${ }^{\mathrm{A}}$, Gonzalo Zavala ${ }^{\mathrm{A}}$ and Belén Luna ${ }^{\mathrm{A}}$ \\ A Department of Environmental Sciences, Faculty of Environmental Sciences, University \\ of Castilla-La Mancha, Avenida de Carlos III s/n, E-45071 Toledo, Spain. \\ ${ }^{B}$ Centro de Investigaciones del Fuego, Campus de la Fábrica de Armas, Avenida de Carlos III s/n, \\ E-45071 Toledo, Spain. \\ ${ }^{\mathrm{C}}$ Corresponding author. Email: josem.moreno@uclm.es
}

\begin{abstract}
In assessing fire risk, it is important to determine whether all areas in a landscape burn at similar rates. This goal is complicated by the limitations of burned-area data and the temporally dynamic nature of landscapes. We assessed the differential degree of forest-fire burning for six landscape variables (land-use-land-cover type, distances to roads and towns, topography (slope, aspect, elevation)), each comprising several categories. The study area $(95 \times 55 \mathrm{~km}) \mathrm{was}$ located in central Spain, and the study period covered 16 years. Landsat multispectral scanner images were used to annually map fire perimeters and to classify the landscape. We calculated an annual resource selection index for each category within a variable. The sizes and shapes of all fires occurring within a year were randomly distributed into the landscape 1000 times, and the corresponding resource selection index was calculated. This provided a null randomburning model against which we tested the actual resource selection index of the fires in each year. Pine woodlands showed consistent and significant positive fire selectivity, whereas deciduous woodlands showed consistent and significant negative selectivity. No differences in the resource selection indices of land-use-land-cover types were found between large $(>100 \mathrm{ha})$ and small fires $(<100 \mathrm{ha})$. Fires positively selected (resource selection index $>1)$ areas at small or intermediate distances to towns and intermediate distances to roads. Selectivity for topographic variables was less marked. Our study demonstrates that landscape variables defining composition (land-use-land-cover type) or proximity to human influence are important factors for fire risk.
\end{abstract}

Additional keywords: fire mapping, fire risk, fire size, global climate change, land-use-land-cover change, landscape structure, Mediterranean ecosystems, Pinus woodlands, wildland-urban interface.

\section{Introduction}

Researchers have debated the relative influences of weather, climate and landscape on fire (Agee 1997). In areas such as boreal forest, landscape composition appears to be a less important determinant of the areas burned by fires (Podur and Martell 2009), although this may vary with location (Cumming 2001; Heyerdahl et al. 2001; Bergeron et al. 2004). In other regions, such as the Mediterranean, fires have differentially burned certain land-use and land-cover (LULC) types (Moreira et al. 2001, 2009; Nunes et al. 2005; Bajocco and Ricotta 2008), suggesting that landscape is a more critical factor in these regions. Minnich (1983) began the debate about the relative roles of landscape and weather or climate in Mediterranean-type areas by attributing the differences in size-frequency distribution of fires in southern California (USA) and northern Baja California (Mexico) to variations in territory management. This idea was later challenged (Moritz 1997; Keeley et al. 1999) on the grounds that, under the severe fire-weather of southern California, fires burn the landscape irrespective of its properties (Moritz 2003). It is not uncommon that very large fires burn old and young stands, the weather overriding much of the landscape characteristics (Keeley et al. 2009).
The identification of which landscape characteristics are most commonly burned is critical for the evaluation of fire risk in any fire-prone area, especially in regions with severe fireweather, such as the Mediterranean region or other similar climate areas of the world. It is important to determine whether fires burn the various classes or categories (e.g. woodlands, shrublands) of a given compositional landscape variable (e.g. LULC type, vegetation type, stand age) in proportion to their relative abundance or whether larger proportions of some classes are likely to burn. Evaluations should similarly consider other landscape variables that potentially affect fire occurrence or spread, such as distance to roads or towns, or topographic features (e.g. slope, aspect, elevation) (Vasconcelos et al. 2001; Badia-Perpinya and Pallares-Barbera 2006). The finding of landscape characteristics that burn more frequently than expected given their abundance would imply that certain changes in the landscape could disproportionably affect fire risk. Hence, increasing the landscape surface cover of an LULC type that burns more frequently than others could increase fire risk. In contrast, in the case that some LULC types burned less frequently than expected, increasing their extent in a landscape could reduce fire risk. Management could then help to diminish 
future increases in fire risk due to climate change (Christensen et al. 2007) or socioeconomic change (Syphard et al. 2008). In contrast, adaptation to increased fire risk due to external drivers must consider other management options in landscapes containing LULC types that burn with similar frequencies.

Furthermore, if fires preferentially burn areas with certain properties, fire effects tend to become concentrated in burnprone areas over time, exacerbating the negative effects of fire in these areas. For example, in a landscape where steeper slopes burn more frequently than in less steep ones or in flat areas, firerelated erosion risk would be higher than that calculated based on average slopes. Such assessments are particularly important in areas facing increased rainfall intensity due to climate change, such as the Mediterranean region (Alcamo et al. 2007). Hence, the proper evaluation of fire risk requires the accurate identification of burn-prone areas through consideration of landscape characteristics that can affect fire occurrence and spread.

Although studies have quantified degrees of burning by LULC type or other landscape variables for many world regions (Cumming 2001; Vázquez and Moreno 2001; Mermoz et al. 2005), many have simply provided averages of the areas burned for the categories of a given variable, or have performed statistical analyses that did not fully account for the nature of burned-area data. First, fires are not normally distributed, and they vary in size by several orders of magnitude (Moreno et al. 1998; Keeley et al. 1999; Boer et al. 2008). Second, burned-area sample units below the level of a single fire are not spatially independent, owing to the contiguous spread of fires through the landscape. Further, fires are temporally and spatially correlated (Chou et al. 1990). Consequently, the assumption of independence between two neighbouring landscape sampling units is inappropriate (Dasgupta and Alldredge 2002). Third, the unit sum constraint indicates that the burned proportions of classes of a landscape variable are not independent of each other. For a landscape variable, an increase in the burned proportion of one class will cause a corresponding decrease in the other classes (Aitchison 1986). Fourth, comparison of the burned proportions of variable classes in areas of different sizes and shapes must take into account the effects of spatial patterning on the distribution of such classes (Wilson et al. 1998). The use of standardised areas or shapes to evaluate differential degrees of burning (Cumming 2001; Moreira et al. 2009; Podur and Martell 2009) must then be conducted with caution. Fifth, landscape characteristics are spatially variable, and fire spread is not independent of these characteristics. For instance, fires tend to stop at particular places, often as a result of changes in vegetation or topography, or where firefighting efforts are most efficient and secure, which, quite commonly, depend on such changes (Davis and Burrows 1994; Viedma et al. 2009). Knowledge of such behaviours must be incorporated into assessments of landscape characteristics burned by fires that compare adjacent burned and unburned areas (Cumming 2001; Moreira et al. 2009; Podur and Martell 2009). Sixth, landscape characteristics are dynamic, and do not remain constant over time, particularly in recently burned areas. Hence, estimates of the abundance of various classes within a given variable (e.g. various LULC types) need to be updated regularly. Any rigorous statistical assessment of the burn rate of landscape variables must consider all of these factors.
The dynamic nature of the landscape deserves particular attention. Landscape hazard varies over time owing, among other factors, to post-fire succession and subsequent fuel accumulation patterns in burned areas. These spatially heterogeneous processes (Turner et al. 1997) change landscape composition and the spatial relationships between various areas. Temporal and spatial fire patterns can be modified as subsequent fires interact with landscape characteristics that can change susceptibility to fire in recently burned areas and their surroundings. In some cases, a fire may create a negative feedback on future burning due to the lack of fuel during early post-fire succession (Niklasson and Granström 2000). In other cases, however, positive feedbacks may be created owing to the high flammability of fuels that develop shortly after a fire (Vilà et al. 2001) and the enhanced connectivity between burned areas (Vázquez and Moreno 2001; Viedma et al. 2006). Given the relevance of these changes in highly humanised landscapes, as in the Mediterranean region, the assessment of fire risk necessitates an understanding of the temporal changes in landscape characteristics as fires continue to occur.

The objective of this study was to determine whether the various classes of several landscape variables were affected by fire in proportion to their relative abundance in a Mediterranean area of central Spain. To achieve this goal, we used annual maps of fire perimeters during a 16-year period, which were projected onto a landscape whose classification was updated annually to account for the changes induced by fires and other factors (Viedma et al. 2006). To circumvent some of the abovementioned shortcomings due to the nature of burned-area data and temporal landscape changes, we adopted a spatially explicit and dynamic approach. We constructed a null model based on the size and shape of the fires that occurred each year; this model was independent of spatial relationships or any other distributional bias of the burned-area data. We tested the degree of relative burning for each class of the following landscape variables: LULC type, distance to roads, distance to towns, slope, aspect and elevation. To examine size-dependent variation in the degree of differential burning, the analysis of LULC type divided fires into small $(<100 \mathrm{ha})$ and large $(>100 \mathrm{ha})$ categories.

\section{Methods}

Study site

The study site comprised a $95 \times 55-\mathrm{km}$ rectangle in central Spain, between the Universal Transverse Mercator (UTM) coordinates $4430000-4485000 \mathrm{Y}$ and $277500-372000 \mathrm{X}$ in Zone 30 North (latitude $39^{\circ} 59^{\prime} 27^{\prime \prime}-40^{\circ} 30^{\prime} 21^{\prime \prime} \mathrm{N}$, longitude $5^{\circ} 36^{\prime} 22^{\prime \prime}-4^{\circ} 30^{\prime} 38^{\prime \prime} \mathrm{W}$; Fig. 1). This mountainous region has a strong south-east-north-west-trending elevation gradient from $\sim 400 \mathrm{~m}$ to more than $2200 \mathrm{~m}$. The substrate is formed by plutonic rocks, mostly granites, with some metamorphic rocks at lower elevations. The soils are deep, siliceous, moderately acidic and quite fertile (Gallardo et al. 1980). The climate is Mediterranean, and is characterised by cold, wet winters and warm, dry summers. Mean temperatures at Arenas de San Pedro, in the lowlands $(510 \mathrm{~m}$ above sea level) of the study area (see Fig. 1), are $14.5^{\circ} \mathrm{C}$ annually, $5.1^{\circ} \mathrm{C}$ in the coldest month and $25.1^{\circ} \mathrm{C}$ in the warmest month. Mean annual precipitation is 


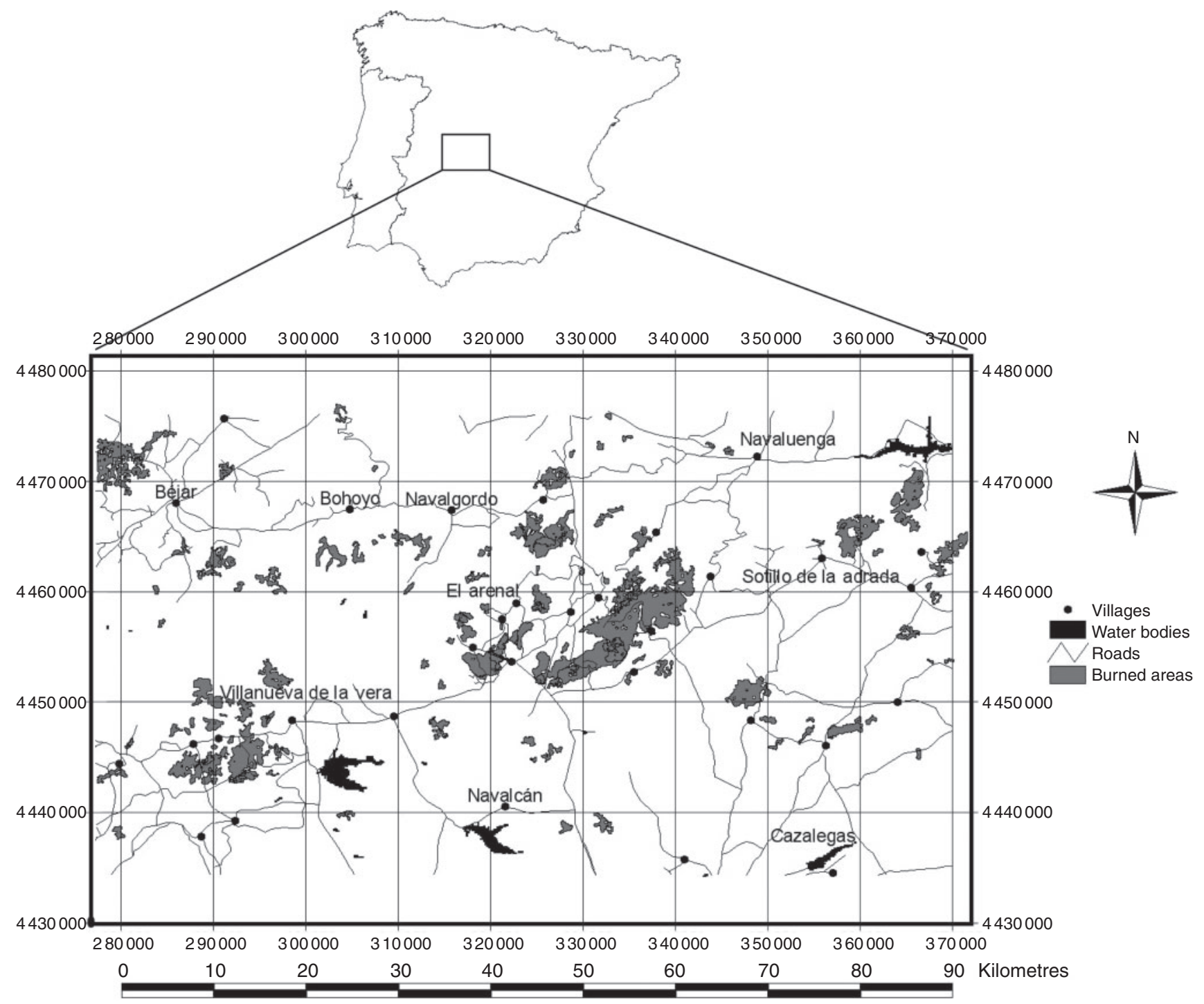

Fig. 1. Location of the study site at Sierra de Gredos, central Spain, and map of the 121 fires that occurred during the study period. A total of 29144 ha (nearly $8 \%$ of the forested area) was burned.

$775 \mathrm{~mm}$, of which $60 \mathrm{~mm}$ fall in the summer. The potential vegetation of the area corresponds to different types of forests and shrublands (Rivas-Martínez 1987), including sclerophyllous oak forest (Pyro bourgaeanae-Quercetum rotundifoliae) to $600 \mathrm{~m}$, humid deciduous oak forest (Arbutus unedonis-Q. pyrenaicae) between 600 and $800 \mathrm{~m}$, sub-humid deciduous oak forest (Luzulo forsteri-Q. pyrenaicae) between 800 and $1600 \mathrm{~m}$, and woody-legume shrublands (Cytiso purganti-Echinospartetum barnadessi) above $1600 \mathrm{~m}$. Owing to human modification, extant vegetation is dominated by dehesas (savanna-type grasslands), pastures, crops, shrublands and pine (Pinus pinaster Aiton) woodlands of human origin.

Imagery analysis, fire mapping and landscape classification

This study used available Landsat multispectral scanner (MSS) data (13 images) for the period 1975-90. This period was the earliest for which satellite images were available and coincided with the national trend of increasing fire occurrence (Moreno et al. 1998). Additionally, forest areas were managed by the same administration during this period; autonomous regional forest authorities were created in 1989. The MSS data and a digital terrain model (DTM) were processed to derive information on LULC types and terrain characteristics respectively for the study area. Landsat MSS images (79-m pixel size) were selected for this study owing to the temporal resolution and span requirements for the classification of land-cover types and the mapping of fire perimeters. The MSS images were obtained from the Landsat 1 through Landsat 5 satellites (1975-78: Path 217, Row 32; 1980-90: Path 202, Row 32). The images were geometrically corrected and radiometrically normalised (for atmospheric and topographic factors; ENVI 1999; see Viedma et al. 2006 for further details). Fires with perimeters $\geq 10$ ha ( $\sim 16$ MSS pixels) were then mapped based on a multitemporal 
analysis of the normalised difference vegetation index (NDVI: $($ MSS4 - MSS2)/(MSS4 + MSS2)), where MSS 4 and MSS 2 are the spectral bands of the near-infrared region (NIR) and the visible red region $(\mathrm{R})$ respectively. The areas burned in each year were identified based on NDVI differences between two consecutive images and unsupervised classification (Viedma et al. 2006). The fire-mapping procedure was verified using aerial photographs for the years 1972 and 1990 and statistics recorded by the Forest Service (Instituto Nacional para la Conservación de la Naturaleza, ICONA) for the period 1975-90. For each fire mapped, we used the Canadian Forest Fire Weather Index (FWI) to calculate the fire-danger conditions at noon on the initial day of the fire. We used data from Cáceres, the city closest to the study area with a long daily record of all variables needed to compute this index.

LULC differences between consecutive years were assessed using a uniformly applied classification system. Annual unsupervised classifications were combined with a knowledge-based method that used decision rules and topographic stratification of the main LULC types to relate spectral classes with real landcover types (see Viedma et al. 2006 for further details). The overall accuracy of the annual LULC classifications was good (overall Kappa $=0.82 \pm 0.09$ ). Seven LULC classes were used: deciduous forests, pine woodlands, shrublands, pastures, crops, dehesas (savanna-type grasslands) and bare soil.

Ancillary information was used to characterise the distance to roads and towns for each area. In order to determine distance to roads, we divided the territory into three categories: $0-1000 \mathrm{~m}$ (39\% of the territory), $1000-3000 \mathrm{~m}(38 \%)$ and $>3000 \mathrm{~m}$ $(23 \%)$. This categorisation sought to proportionately divide the territory, assuming that human influence is greatest close to roads and decreases with distance in a non-linear fashion (Wittenberg and Malkinson 2009). In determining distance to towns, we divided the territory into three categories: 0-2000 m (8\%), 2000-5000 $\mathrm{m} \mathrm{(31 \% )} \mathrm{and} \mathrm{>5000} \mathrm{m}(61 \%)$. Because few towns are located in or near the study area, a more equitable distribution was not possible. The first town category represented twice the distance of the first road category because the distance to towns was measured to town centres and the median maximum length of towns was $1000 \mathrm{~m}$. The first town category thus sought to include at least $1000 \mathrm{~m}$ beyond the town limits. The second town category took into consideration the $\sim 8000-\mathrm{m}$ median distance between towns. A distance that exceeded the midpoint between towns by $1000 \mathrm{~m}$ was considered to mark the limit of high town influence. Areas located $5000 \mathrm{~m}$ or more from towns were considered to be distant from them.

Topographic characteristics were categorised by elevation (10 200 -m increments from 200 to $>2000 \mathrm{~m}$ : (1) 200-400 m; (2) 400 $600 \mathrm{~m}$; (3) $600-800 \mathrm{~m}$; (4) $800-1000 \mathrm{~m}$; (5) $1000-1200 \mathrm{~m}$; (6) 1200-1400 m; (7) 1400-1600 m; (8) 1600-1800 m; (9) 1800$2000 \mathrm{~m}$; (10) 2000-2200 m); slope (five categories in 10\% increments from $<10 \%$ to $>40 \%$ : $<10 \% ; 10-20 \% ; 20-30 \% ; 30$ $40 \% ;>40 \%$ ) and exposure (flat: pixels with adjacent areas at the same elevation on a digital elevation model (DEM); and eight $45^{\circ}$ aspect classes, whereby $\mathrm{N}=337.5-22.5^{\circ}, \mathrm{NE}=22.5-67.5^{\circ}$, etc.).

\section{Habitat selection by fires and Monte Carlo simulations}

To evaluate whether a given class within any of the six landscape variables burned more frequently than others within the same variable, we calculated a resource selection index (RSI). The RSI is commonly used in studies of habitat selectivity by animals (Manly et al. 1993). We used Savage's (1931) forage ratio: $\boldsymbol{w}_{\boldsymbol{i}}=\boldsymbol{U}_{\boldsymbol{i}} / \boldsymbol{A}_{\boldsymbol{i}}$, where $\boldsymbol{U}_{\boldsymbol{i}}$ is the ratio of resource $\boldsymbol{i}$ used to all resources used, and $\boldsymbol{A}_{\boldsymbol{i}}$ is the ratio of available resource $\boldsymbol{i}$ to all available resources. The indices were calculated as follows for LULC types (similar calculations were made for the other variable): $\boldsymbol{U}_{\boldsymbol{i}}$ designated the area of LULC class $\boldsymbol{i}$ burned by each fire divided by the total area of that fire, and $\boldsymbol{A}_{i}$ represented the area covered by LULC class $i$ in the entire study site divided by the total area of the study site. A class with a burned area proportionate to its availability was thus represented by the value $\boldsymbol{w}=1$, a class with a burned area exceeding that expected by chance (i.e. 'selected' by a fire) had a value $\boldsymbol{w}>1$, and a class with a less-than-expected burned area (i.e. 'avoided' by a fire) had a value $\boldsymbol{w}<1$.

The $\boldsymbol{w}_{i}$ ratios for the classes comprising each variable were first calculated by year, using the actual sizes, shapes and locations of fire perimeters. The fire perimeters were then transformed from a raster form to vector points, and we constructed a null model for each RSI, based on Monte Carlo simulations, by randomly distributing all fires in each year over the image of that year 1000 times. Three random numbers were subsequently used as the new easting and northing coordinates and angle of rotation for each fire perimeter. Random burn images were then constructed while maintaining the size and shape of each fire and avoiding overlap between fires in the same year. We also assumed that fire could not propagate through non-burnable areas (e.g. water bodies, towns). After this pseudo-population of random burning was constructed for each year, RSIs and statistical distributions were calculated for the classes of each landscape variable.

The RSI $\boldsymbol{w}_{i}$ values from the 1000 random images for each year were used to calculate a $95 \%$ confidence interval for the analysis of observed $v$. expected values (Bailey and Gatrell 1995). Selection of a given class within a variable was considered to be significantly positive when the percentile values for the real fires $\left(\mathrm{P}_{\mathrm{i}}\right)$ exceeded the 95 th percentile $\left(\mathrm{P}_{95}\right)$, and significantly negative when the $\mathrm{P}_{\mathrm{i}}$ values for the real fires were below the 5th percentile $\left(\mathrm{P}_{5}\right)$. When $\mathrm{P}_{\mathrm{i}}$ values for the real fires fell between these values, no significant selection was considered to have occurred (Wilson et al. 1998). These calculations were performed for all fires and for fires divided by size, based on the classification commonly used by forest fire agencies (small: $<100$ ha, large: $>100$ ha). To test the association between selectivity and year, a goodness-of-fit test (for $n<100$ ) was performed for each $\boldsymbol{w}_{i}$ RSI during all years of study.

Our approach assessed selectivity towards each landscape variable independently of other variables, although such independence cannot be assumed. The large number of class and variable combinations precluded their combined analysis.

\section{Results}

The LULC types occurred within the study area in the following proportions: deciduous forests, $3.0 \%$; pine woodlands, $10.3 \%$; shrublands, 29.4\%; pastures, 31.4\%; crops, 10.6\%; dehesas, $13.6 \%$; and bare and non-burnable areas, $1.7 \%$. During the 16-year study period, 121 fires burned a total area of 29144 ha 

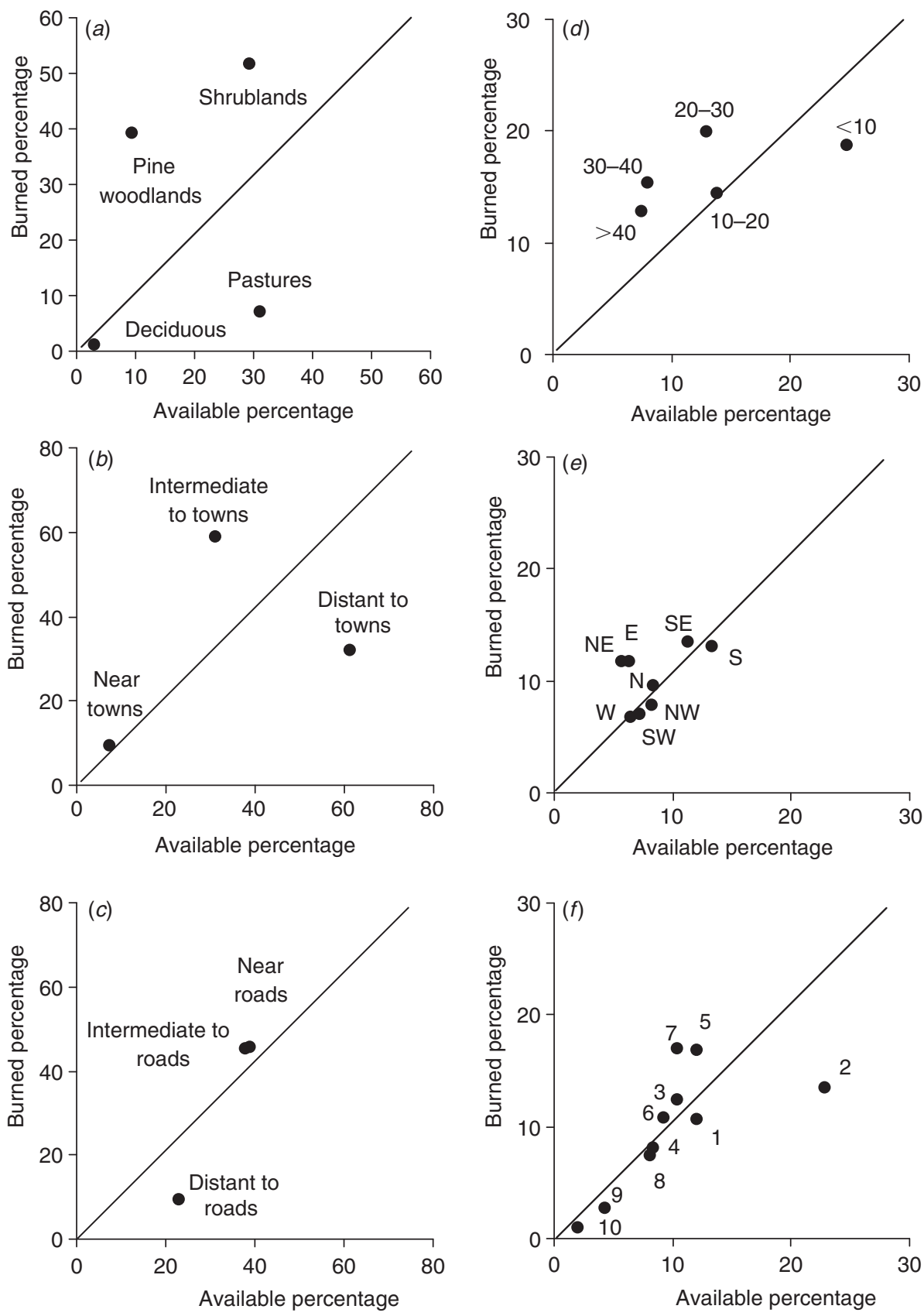

Fig. 2. Percentage of burned area with respect to available area for: (a) land-use-land-cover type; $(b)$ distance to towns; $(c)$ distance to roads; $(d)$ slope; $(e)$ aspect; and $(f)$ elevation. See the Methods section for explanation of variable classes. Areas above the line burned in greater proportions than expected given their abundance.

(nearly $8 \%$ of the forested area; Fig. 1). Fire size ranged from 13 to 5008 ha, with fires of 50-200 ha occurring most frequently ( $80 \%$ of the total). Most (65\%) fires were started by people; $45 \%$ were arson, $20 \%$ were due to negligence, $32 \%$ were caused by unknown sources, and 3\% by lightning. Most fires burned under extreme fire danger conditions $(\mathrm{FWI}>30)$. Because fire directionality was unknown, we could not calculate the actual maximum distance travelled by each fire. We instead used the longest axis of each fire perimeter to represent the maximum distance covered by fire. The median longest-axis value of the fire perimeters was $\sim 1400 \mathrm{~m}$. Ignition points were also unknown; assuming that the fire propagated outwards from roads or towns, we used the least distance of a fire perimeter to either of them as an approximation to determine the closest ignition point to roads or towns. The median least-distance value of fire perimeters to roads was $500 \mathrm{~m}$, and that to towns was $\sim 3000 \mathrm{~m}$. The minimum distance of fire perimeters to roads was $<100 \mathrm{~m}$, and that to towns was $800 \mathrm{~m}$. 


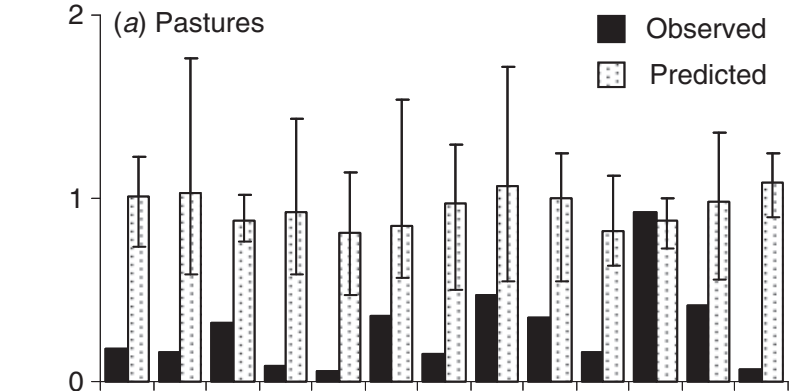

$3\urcorner$ (b) Shrublands

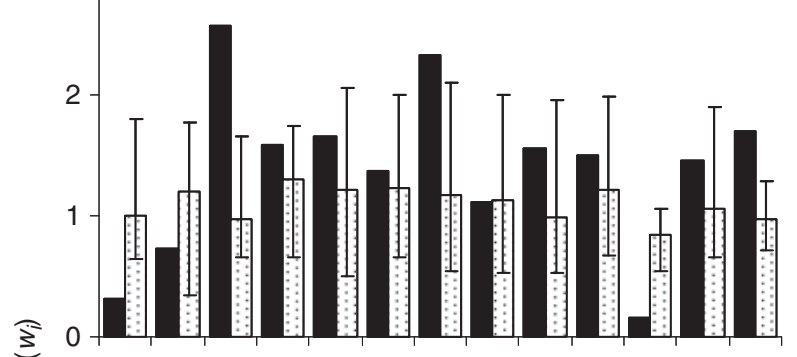

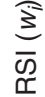

(c) Deciduous forests

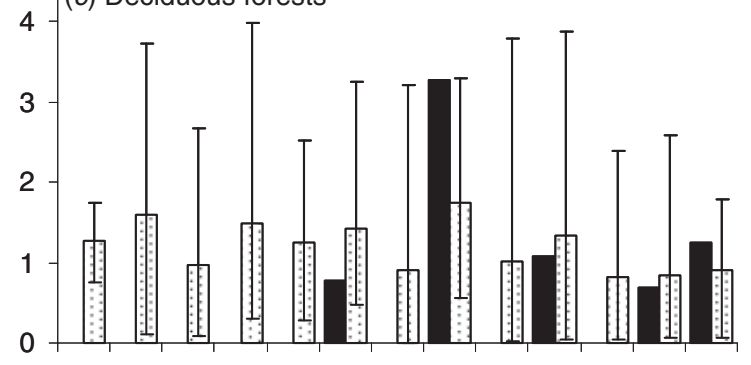

(d) Pine woodlands

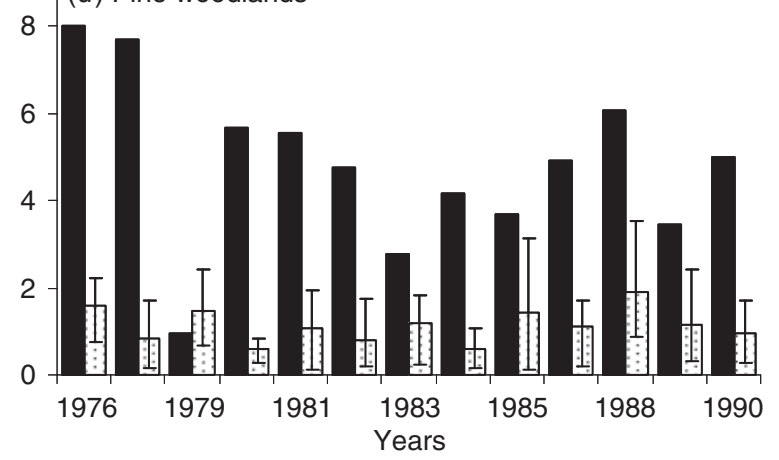

Fig. 3. Observed and predicted values of the resource selection indices (RSI: $\boldsymbol{w}_{\boldsymbol{i}}$ ) calculated for land-use-land-cover types for all fires during the period 1975-90: $(a)$ pastures; $(b)$ shrublands; $(c)$ deciduous forests; and (d) pine woodlands.

Fires burned differentially according to LULC class, distance to roads or towns and topographic characteristics (Fig. 2). Some LULC classes burned in greater proportion than their abundance (above the 1:1 line), indicating positive selection, and others burned in lesser proportion (below the $1: 1$ line), indicating negative selection (Figs 3, 4). Pine woodlands showed consistent and highly positive selection (RSI $\boldsymbol{w}_{\boldsymbol{i}}>1 ; \mathrm{P}_{\mathrm{i}}>\mathrm{P}_{95}$ ). Shrublands showed no significant fire selectivity over time (Table 1); the RSI $\boldsymbol{w}_{\boldsymbol{i}}$ ratio exceeded the $\mathrm{P}_{95}$ of the random-burning
+Selection $\mathbb{Q}-$ Selection $\square$ No selection

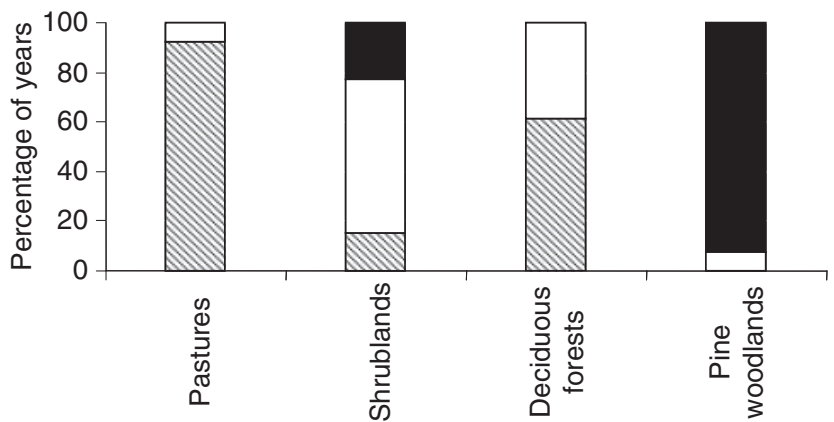

Land-use and land-cover

Fig. 4. Percentage of years in which fire showed a significantly positive $(+)$ or negative $(-)$ selection, or no selection $(0)$, for the land-use-landcover classes.

distribution on only three occasions. Deciduous forests and pastures were characterised by negative fire selectivity (Table 1). The analysis of fires divided by size produced similar results (Figs 5, 6). The RSIs for the LULC classes were thus independent of fire size.

A greater proportion of fires burned at intermediate distances $(1000-3000 \mathrm{~m})$ to roads than at closer or more distant locations (Fig. 7a), exhibiting consistent and significant positive fire selectivity (Table 1). Areas close to towns and at intermediate distances showed positive fire selectivity, whereas areas more distant from towns were not selected (Fig. 7b, Table 1).

Fires burned most frequently in the steepest areas $(>20 \%$ slope), particularly those with $30-40 \%$ slopes (Fig. $8 a$ ), but consistent selectivity could not be statistically validated (Table 1). Areas facing north, north-east and east burned most frequently (Fig. $8 b$ ), but only east-facing areas showed significant positive selectivity (Table 1). Finally, areas at the lowest and highest elevations (Fig. 8c) exhibited consistent and significant negative selectivity (Table 1). Although positive selection most frequently occurred at intermediate elevations, this selectivity was not statistically validated over the years (Table 1).

\section{Discussion}

Fires differentially burned the LULC types comprising the study landscape. Some LULC classes burned in greater proportion than expected given their relative abundance, whereas others burned in lesser proportion. Pine woodlands, which have highly flammable litter (Elvira and Hernando 1989), showed the highest RSI, indicating positive fire selectivity. Fire burned this LULC type nearly every year during the study period. Syphard et al. (2009) have shown that needle-leaf forests burn disproportionately more than other vegetation types across the Mediterranean Basin. Shrublands also showed positive fire selectivity $(\mathrm{RSI}>1)$ in the present study, but with lower and less consistently significant RSIs than those of pine woodlands. All other LULC types showed negative fire selectivity $(\mathrm{RSI}<1)$; deciduous woodlands and pastures were characterised by particularly constant negative selection. 
Table 1. Chi-square and $\boldsymbol{P}$ values from the goodness-of-fit test for the association between fire selectivity (negative $(-)$, positive $(+)$ or no selection (non)) and years for the classes of landscape variables: landuse-land-cover (LULC) type, distance to roads and towns and topography (slope, aspect, elevation)

$* 0.05 \geq P>0.01 ; * * 0.01 \geq P>0.001 ; * * * P \leq 0.001$; NS, not significant

\begin{tabular}{|c|c|c|c|c|}
\hline & \multicolumn{4}{|c|}{ Randomisation test } \\
\hline & $x^{2}$ & $\mathrm{P}$ & Selectivity & Significance \\
\hline \multicolumn{5}{|l|}{ LULC } \\
\hline Pastures & 20.462 & $<0.001$ & $(-)$ & $* * *$ \\
\hline Shrublands & 4.769 & 0.100 & & NS \\
\hline Deciduous & 7.538 & 0.030 & $(-)$ & $*$ \\
\hline Pine woodlands & 20.462 & $<0.001$ & $(+)$ & $* * *$ \\
\hline \multicolumn{5}{|l|}{ Distance to roads $(\mathrm{m})$} \\
\hline$<1000$ & 6.615 & 0.045 & non & $*$ \\
\hline $1000-3000$ & 9.385 & 0.010 & $(+)$ & $*$ \\
\hline$>3000$ & 2.462 & 0.370 & & NS \\
\hline \multicolumn{5}{|l|}{ Distance to towns (m) } \\
\hline$<2000$ & 11.231 & 0.005 & $(+)$ & $* *$ \\
\hline $2000-5000$ & 12.154 & $<0.001$ & $(+)$ & $* * *$ \\
\hline$>5000$ & 15.846 & $<0.001$ & non & $* * *$ \\
\hline \multicolumn{5}{|l|}{ Slope ranges $(\%)$} \\
\hline$<10$ & 9.385 & $<0.001$ & non & $* * *$ \\
\hline $10-20$ & 5.692 & 0.060 & & NS \\
\hline $20-30$ & 9.385 & 0.015 & non & $*$ \\
\hline $30-40$ & 6.615 & 0.025 & non & $*$ \\
\hline$>40$ & 2.923 & 0.270 & & NS \\
\hline \multicolumn{5}{|l|}{ Aspect ranges $\left({ }^{\circ}\right)$} \\
\hline Flat & 7.538 & 0.035 & non & $*$ \\
\hline $\mathrm{N}(337.5-22.5)$ & 0.615 & 0.825 & & NS \\
\hline $\operatorname{NE}\left(22.5-67.5^{\circ}\right)$ & 3.846 & 0.180 & & NS \\
\hline $\mathrm{E}\left(67.5-112.5^{\circ}\right)$ & 6.615 & 0.015 & $(+)$ & $*$ \\
\hline $\operatorname{SE}\left(112.5-157.5^{\circ}\right)$ & 1.077 & 0.675 & & NS \\
\hline$S\left(157.5-202.5^{\circ}\right)$ & 11.231 & $<0.001$ & non & $* * *$ \\
\hline SW $\left(202.5-247.5^{\circ}\right)$ & 11.231 & $<0.001$ & non & $* * *$ \\
\hline $\mathrm{W}\left(247.5-292.5^{\circ}\right)$ & 2.923 & 0.275 & & NS \\
\hline NW $\left(292.5-337.5^{\circ}\right)$ & 4.769 & 0.125 & & NS \\
\hline \multicolumn{5}{|l|}{ Elevation ranges $(\mathrm{m})$} \\
\hline $200-400$ & 7.538 & 0.025 & $(-)$ & $*$ \\
\hline $400-600$ & 12.154 & 0.010 & non & $*$ \\
\hline $600-800$ & 15.385 & $<0.001$ & non & $* * *$ \\
\hline $800-1000$ & 12.154 & 0.005 & non & $* *$ \\
\hline $1000-1200$ & 5.692 & 0.045 & non & $*$ \\
\hline $1200-1400$ & 7.538 & 0.025 & non & $*$ \\
\hline $1400-1600$ & 7.538 & 0.025 & non & $*$ \\
\hline $1600-1800$ & 15.385 & $<0.001$ & non & $* * *$ \\
\hline $1800-2000$ & 4.308 & 0.175 & & NS \\
\hline $2000-2200$ & 12.154 & $<0.001$ & $(-)$ & $* * *$ \\
\hline
\end{tabular}

The positive selection for pine woodlands over shrublands, which are also highly flammable and combustible, and the negative selection for deciduous woodlands suggest that changes in landscape composition may affect fire occurrence and patterns in this region. Such land-use modifications may occur through forestation (increasing pine woodland proportions) or abandonment (increasing shrubland proportions). Our results support the contention that the land-use changes that have been common since the mid-20th century around the Mediterranean Basin (Moreira et al. 2001; Mouillot et al.
2003; Romero-Calcerrada and Perry 2004) may have had important consequences on burn rates. The high degree of afforestation with conifers during the second half of the 20th century (Pausas et al. 2008) may have contributed to increased fire hazard throughout the Mediterranean (Wittenberg and Malkinson 2009). The results of the present study suggest that afforestation projects in fire-prone areas that aim to achieve environmental goals, such as increasing carbon-sink capacity or deterring desertification processes, must be implemented cautiously. This is particularly true for projects that use highly flammable species, such as pines. Our negative fire selectivity results for deciduous woodlands suggest that environmental goals may be achieved while minimising fire risk through the use of such LULC types.

Our results indicate that landscape composition and structure are important factors affecting fire patterns in this region. Although the region is characterised by severe fire-weather conditions, these conditions vary widely and further research must explore differential fire selectivity in relation to them. If selectivity depends on the weather conditions under which fire propagates, larger fires, which commonly occur under severe weather conditions, should spread over large areas of the landscape regardless of available LULC types. Fires occurring under moderate weather conditions should be smaller, and fuel type should exert a stronger influence on fire propagation. Hence, a higher selectivity towards flammable fuels (i.e. pine woodlands) would be expected. However, our data do not support this argument, as the RSI indices of the LULC classes varied little between small and large fires.

In the Mediterranean Basin (Pausas 2004) and other areas (Stephens 2005; Westerling et al. 2006; Littell et al. 2009; Lutz et al. 2009), interannual climate variability is an important determinant of yearly burned area. A close relationship has also been found between fire-size patterns and meteorological patterns during the fire season (Boer et al. 2008). Larger fires are expected, to a certain extent, to burn the landscape regardless of its characteristics (e.g. vegetation, stand age) (Keeley et al. 2009). Our fire data, which had few very large fires ( $>500 \mathrm{ha})$, may not have been appropriate for the detection of size- and fire danger-related changes in fire selectivity. Nevertheless, the median FWI of our fires was within the $\mathrm{P}_{65}$ of the FWI distribution for the warmest months (June-September) on record, and seven fires $(6 \%)$ exceeded the $\mathrm{P}_{95}$ of this distribution. Therefore, the fires in our sample did occur within the regional range of extreme conditions. Given the limited number of fires in our sample, it was impractical to test whether the selectivity of fires occurring in the upper range of fire-danger conditions differed from that of fires occurring under less extreme conditions. Such analysis is important, however, given the climate projections for this region; the mean FWI during the warmest months (June-September) is projected to increase by as much as $75 \%$ by the end of the 21 st century and for two of the most common emission scenarios (Moreno et al. 2010). Assuming that other landscape characteristics remain unaltered, climate change may produce more extreme conditions than observed in recent times.

We expected that more sites located near roads would burn than those at intermediate or greater distances, because most fires were ignited by people and roads were the expected entry 


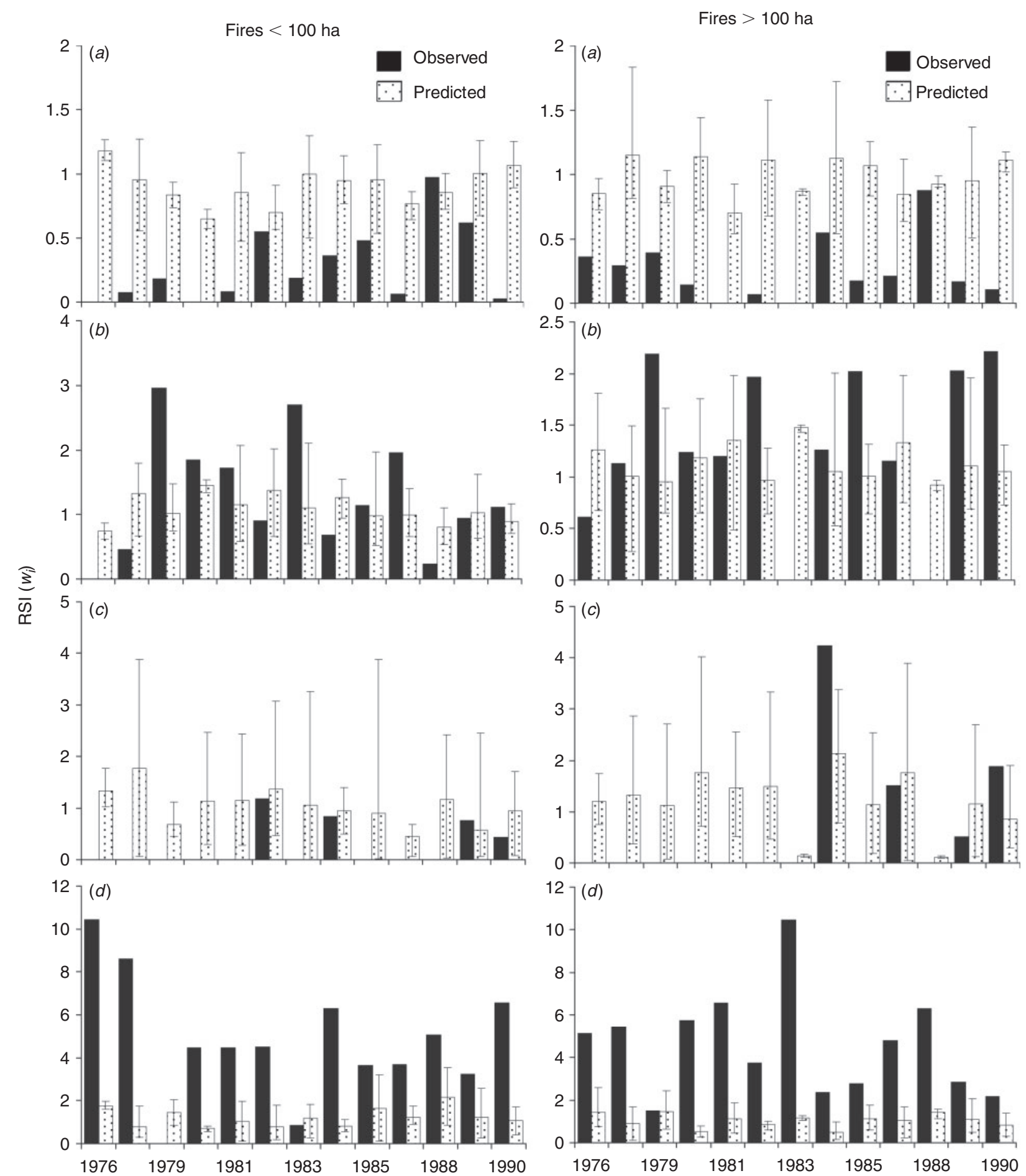

Fig. 5. Observed and predicted values of the resource selection indices (RSI: $\boldsymbol{w}_{\boldsymbol{i}}$ ) calculated for land-use-land-cover types for fires classified by size (left: $<100$ ha; right: $>100$ ha) during the period 1975-90: $(a)$ pastures; $(b)$ shrublands; $(c)$ deciduous forests; and $(d)$ pine woodlands.

and escape routes for arson or sources of accidental ignition (Vasconcelos et al. 2001; Romero-Calcerrada et al. 2008; Wittenberg and Malkinson 2009). However, we found that burning was significantly more frequent at intermediate distances. This finding may reflect the spreading of fires ignited close to roads into the next distance-to-roads class
(1000-3000 m), depending on the maximum length of the fire perimeter and the estimated point of ignition. Although ignition points were unknown, the median maximum length of the fire perimeters exceeded $1000 \mathrm{~m}$, and only $30 \%$ of perimeters had a maximum length of $1000 \mathrm{~m}$ or less. Furthermore, the median nearest distance to a road was $500 \mathrm{~m}$. Assuming that fires 
(a) $<100$ ha

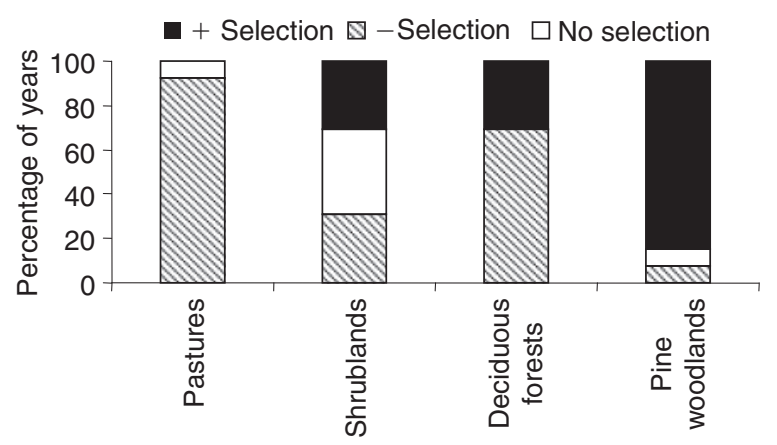

Land-use and land-cover type (b) $>100$ ha

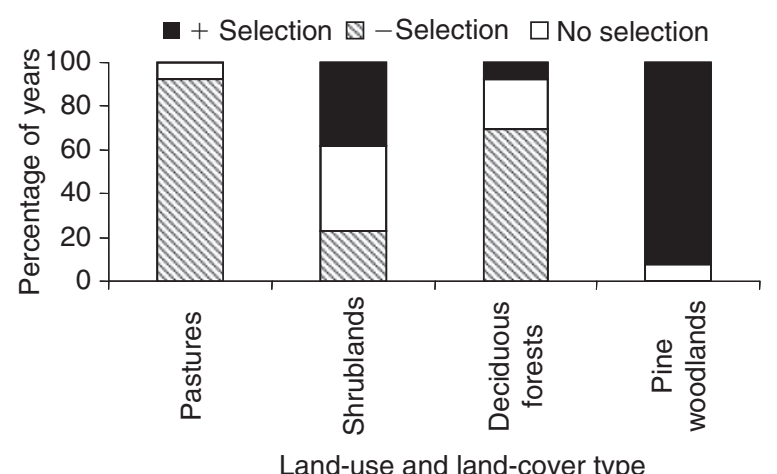

Fig. 6. Percentage of years in which fires classified by size showed a significant positive or negative selection, or no selection, for land-useland-cover classes: $(a)<100$ ha; $(b)>100$ ha.
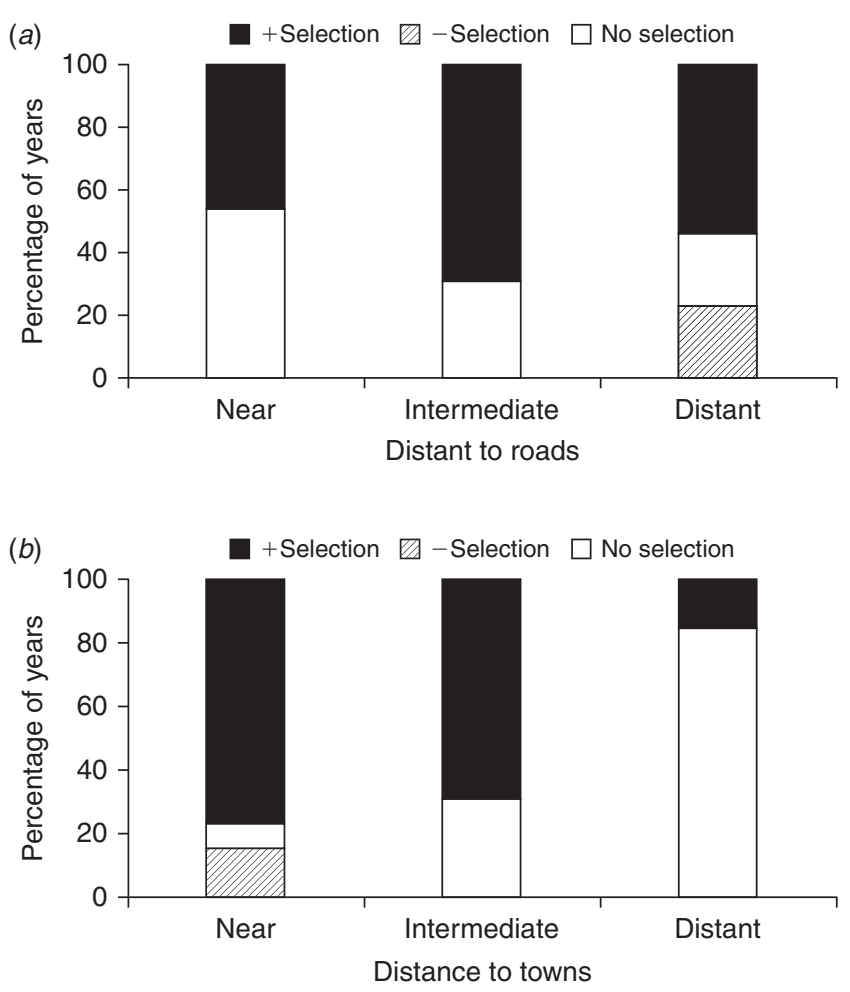

Fig. 7. Percentage of years in which fire showed a statistically significant positive $(+)$ or negative selection $(-)$, or no selection, for different distances to $(a)$ roads, and $(b)$ towns. Distance-to-road classes are: near $(0-1000 \mathrm{~m})$, intermediate $(1000-3000 \mathrm{~m})$, and distant $(>3000 \mathrm{~m})$. Distance-to-town classes are: close $(0-2000 \mathrm{~m})$, intermediate $(2000-5000 \mathrm{~m})$, and distant $(>5000 \mathrm{~m})$.

propagated outwards from roads, at least $50 \%$ of the fires in our sample were lit several hundred metres $(\geq 500 \mathrm{~m})$ inside the first distance-to-roads class $(0-1000 \mathrm{~m})$. Consequently, they propagated well into the intermediate distance-to-roads class of the landscape, making it the most commonly burned. We also found that some fires spread up to less than $100 \mathrm{~m}$ from roads, and that half of the fire perimeters had a nearest distance to roads of less than $500 \mathrm{~m}$, indicating that roads acted as ignition points or entry routes. These results confirm those of other studies conducted in nearby areas (Romero-Calcerrada et al. 2008) and elsewhere in the Mediterranean (Wittenberg and Malkinson 2009).

Distance to towns and urban areas has also been a significant variable in models evaluating fire-risk factors (Cardille et al. 2001; Badia-Perpinya and Pallares-Barbera 2006; RomeroCalcerrada et al. 2008). We expected more fires at intermediate distances to towns than at closer or more distant locations, because agricultural land predominates closer to towns, where land-use is often less intense, and vegetative cover is greater at more distant locations. The density of ignitions due to negligence or accidental causes should thus decrease with distance from towns, but the combined effects of more fuel at greater distances and less fuel near towns would cause a greater proportion of intermediate areas to burn. This argument is supported by the documentation of highest fire frequency and largest burned area at locations characterised by intermediate levels of human activity in landscapes where most fires are ignited by people (Syphard et al. 2008). Our results show consistent positive fire selectivity at intermediate distances to towns, but also at locations closer to towns. Given that the median nearest distance of fire perimeters to towns was $\sim 3000 \mathrm{~m}$, and that $30 \%$ of fires had a nearest distance to town of $2000 \mathrm{~m}$, towns appear to have been a major source of ignitions. As towns were also close to one another (median nearest inter-town distance $=8000 \mathrm{~m}$ ), fires started in one town could have affected the neighbouring town. The proximity among towns and the availability of fuels around and between them likely interacted to produce the observed spatial pattern of burning, whereby a continuum of high fire-risk areas encircled towns to a distance of $\sim 5000 \mathrm{~m}$. This finding has clear implications for the planning of regional urban development with the goal of minimising fire risk.

Our results partially supported the argument that topographic variables play a role in fire (Agee 1997), although selectivity towards them was less pronounced and consistent than for other variables. Steep areas burned more frequently than expected, but they did not exhibit consistent and significant positive selectivity. Northern, north-eastern and eastern exposures 

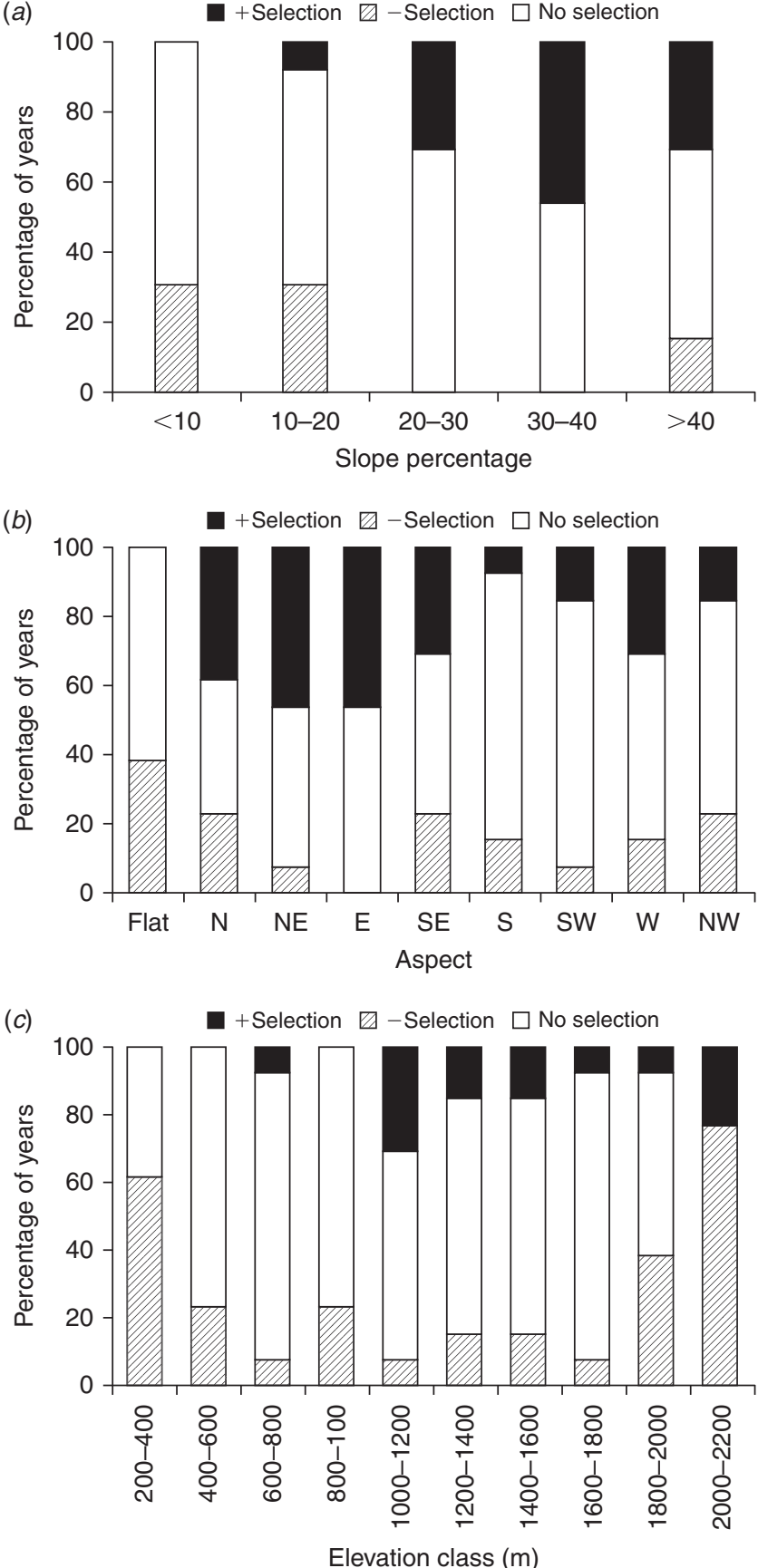

Fig. 8. Percentage of years in which fires showed a statistically significant positive $(+)$ or negative selection $(-)$, or no selection, for different topographic variables: $(a)$ slope, $(b)$ aspect, and $(c)$ elevation.

burned more often than others, perhaps due in part to the prevailing north-western wind patterns (fires would thus burn uphill and downwind) and favourable mesic conditions for fuel accumulation on these slopes. Selectivity for exposure, however, was weak over time. Areas located at lower or higher elevation showed strong and consistent negative selectivity, but no selectivity was found for the other, intermediate elevations.
The procedure used in this study allows the assessment of fire's differential selectivity for the various types of patches that make up a landscape, taking into account the nature of burned-area data and landscape dynamics. This methodology may be useful in studies that seek to establish the risks associated with vegetation types, stand age, management treatments, landscape patterns, or other fire-relevant properties, and complements other approaches. This approach also allows comparisons of fires by weather conditions, fire size or sources of ignition, among others. Our approach does not integrate all variables into a single model, precluding the analysis of interactions among them. Such integration is particularly challenging when landscape dynamics are considered. Nevertheless, this procedure permits robust hypothesis testing for particular landscape variables that are thought to play a major role in fire.

\section{Acknowledgements}

This study was supported by funding from the European Commission projects ENV4-CT96-0320 and EVG-CT-2001-0043.

\section{References}

Agee JK (1997) The severe weather wildfire - too hot to handle? Northwest Science 71, 153-156

Aitchison J (1986) 'The Statistical Analysis of Compositional Data.' (Chapman and Hall: London)

Alcamo J, Moreno JM, Nováky B, Bindi M, Corobov R, Devoy RJN, Giannakopoulos C, Martin E, Olesen JE, Shvidenko A (2007) Europe. In 'Climate Change 2007: Impacts, Adaptation and Vulnerability. Contribution of Working Group II to the Fourth Assessment Report of the Intergovernmental Panel on Climate Change'. (Eds ML Parry, OF Canziani, JP Palutikof, PJ van der Linden, CE Hanson) pp. 541-580. (Cambridge University Press: Cambridge, UK).

Badia-Perpinya A, Pallares-Barbera M (2006) Spatial distribution of ignitions in Mediterranean periurban and rural areas: the case of Catalonia International Journal of Wildland Fire 15, 187-196. doi:10.1071/ WF04008

Bailey TC, Gatrell AC (1995) 'Interactive Spatial Data Analysis.' (Longman Group Limited: Harlow, Essex, UK)

Bajocco S, Ricotta C (2008) Evidence of selective burning in Sardinia (Italy): which land-cover classes do wildfires prefer? Landscape Ecology 23, 241-248. doi:10.1007/S10980-007-9176-5

Bergeron Y, Gauthier S, Flannigan M, Kafka V (2004) Fire regimes at the transition between mixedwood and coniferous boreal forest in northwestern Quebec. Ecology 85, 1916-1932. doi:10.1890/02-0716

Boer MM, Sadler RJ, Bradstock RA, Gill AM, Grierson PF (2008) Spatial scale invariance of southern Australian forest fires mirrors the scaling behaviour of fire-driving weather events. Landscape Ecology 23, 899-913

Cardille JA, Ventura SJ, Turner MG (2001) Environmental and social factors influencing wildfires in the Upper Midwest, United States. Ecological Applications 11, 111-127. doi:10.1890/1051-0761(2001) 011[0111:EASFIW]2.0.CO;2

Chou YH, Minnich RA, Salazar LA, Power JD, Dezzani RJ (1990) Spatial autocorrelation of wildfire distribution in the Idyllwild quadrangle, San Jacinto Mountain, California. Photogrammetric Engineering and Remote Sensing 56, 1507-1513

Christensen JH, Hewitson B, Busuioc A, Chen Z, Gao AX, Held I, Jones R, Kolli RK, Kwon W-T, Laprise R, Magaña Rueda V, Mearns L, Menéndez CG, Räisänen J, Rinke A, Sarr A, Whetton P (2007) Regional climate projections. In 'Climate Change 2007: the Physical Science Basis - Contribution of Working Group I to the Fourth Assessment Report of the Intergovernmental Panel on Climate Change'. 
(Eds S Solomon, D Qin, M Manning, Z Chen, M Marquis, KB Averyt, M Tignor, HL Miller) pp. 847-940. (Cambridge University Press: Cambridge, UK)

Cumming SG (2001) Forest type and wildfire in the Alberta boreal mixedwood: what do fires burn? Ecological Applications 11, 97-110. doi:10.1890/1051-0761(2001)011[0097:FTAWIT]2.0.CO;2

Dasgupta N, Alldredge JR (2002) A single-step method for identifying individual resources. Journal of Agricultural Biological \& Environmental Statistics 7, 208-221. doi:10.1198/10857110260141247

Davis FW, Burrows DA (1994) Spatial simulation of fire regime in Mediterranean-climate landscapes. In 'The Role of Fire in Mediterranean-type Ecosystems'. (Eds JM Moreno, WC Oechel) pp. 117-139. (Springer-Verlag: New York)

Elvira LM, Hernando C (1989) 'Inflamabilidad y Energía de las Especies de Sotobosque: Estudio Piloto con Aplicación a los Incendios Forestales.' (Monografías Instituto Nacional de Investigaciones Agrarias: Madrid)

ENVI (1999) 'The Environment for Visualizing Images Software.' (Lafayette, $\mathrm{CO}$ )

Gallardo JF, Cuadrado SY, González-Hernández MI (1980) Suelos forestales de la vertiente sur de la Sierra de Gredos. VII Anuario del Centro de Edafología y Biología Aplicada de Salamanca, Instituto de Orientación y Asistencia Técnica del Oeste, Consejo Superior de Investigaciones Científicas (CSIC), pp. 155-168.

Heyerdahl EK, Brubaker LB, Agee JK (2001) Spatial controls of historical fire regimes: a multiscale example from the interior west, USA. Ecology 82, 660-678. doi:10.1890/0012-9658(2001)082[0660:SCOHFR]2.0.CO;2

Keeley JE, Fotheringham CJ, Morais M (1999) Re-examining fire suppression impacts on brushland fire regimes. Science 284, 18291832. doi:10.1126/SCIENCE.284.5421.1829

Keeley JE, Safford H, Fotheringham CJ, Franklin J, Moritz M (2009) The 2007 southern California wildfires: lessons in complexity. Journal of Forestry 107, 287-296

Littell JS, McKenzie D, Peterson DL, Westerling AL (2009) Climate and wildfire area burned in western US ecoprovinces. Ecological Applications 19, 1003-1021. doi:10.1890/07-1183.1

Lutz JA, van Wagtendonk JW, Thode AE, Miller JD, Franklin JF (2009) Climate, lightning ignitions, and fire severity in Yosemite National Park, California, USA. International Journal of Wildland Fire 18, 765-774. doi:10.1071/WF08117

Manly BF, McDonald LL, Thomas DL (1993) 'Resource Selection by Animals: Statistical Design and Analysis for Field Studies.' (Chapman \& Hall: London)

Mermoz M, Kitzberger T, Veblen TT (2005) Landscape influences on occurrence and spread of wildfires in Patagonian forests and shrublands. Ecology 86, 2705-2715. doi:10.1890/04-1850

Minnich RA (1983) Fire mosaics in southern California and northern Baja California. Science 219, 1287-1294. doi:10.1126/SCIENCE.219. 4590.1287

Moreira F, Rego FC, Ferreira PG (2001) Temporal (1958-1995) pattern of change in a cultural landscape of north-western Portugal: implications for fire occurrence. Landscape Ecology 16, 557-567. doi:10.1023/ A: 1013130528470

Moreira F, Vaz P, Catry F, Silva JS (2009) Regional variations in wildfire susceptibility of land-cover types in Portugal: implications for landscape management to minimize fire hazard. International Journal of Wildland Fire 18, 563-574. doi:10.1071/WF07098

Moreno JM, Vázquez A, Vélez R (1998) Recent history of forest fires in Spain. In 'Large Forest Fires'. (Ed. JM Moreno) pp. 159-185. (Backhuys Publishers: Leiden, the Netherlands)

Moreno JM, Zavala G, Martín M, Millán A (2010) Forest fire risk in Spain under future climate change. In 'Atlas of Biodiversity Risks'. (Eds J Settele, LD Penev, TA Georgiev, R Grabaum, V Grobelnik, V Hammen, S Klotz, M Kotarac, I Kuehn) pp. 72-73. (Pensoft: Sofia, Bulgaria)
Moritz MA (1997) Analyzing extreme disturbance events: fire in Los Padres National Forest. Ecological Applications 7, 1252-1262. doi:10.1890/ 1051-0761(1997)007[1252:AEDEFI]2.0.CO;2

Moritz MA (2003) Spatiotemporal analysis of controls on shrubland fire regimes: age dependency and fire hazard. Ecology 84, 351-361. doi:10.1890/0012-9658(2003)084[0351:SAOCOS]2.0.CO;2

Mouillot F, Ratte JP, Joffre R, Moreno JM, Rambal S (2003) Some determinants of the spatio-temporal fire cycle in a Mediterranean landscape (Corsica, France). Landscape Ecology 18, 665-674. doi:10.1023/B:LAND.0000004182.22525.A9

Niklasson M, Granström A (2000) Numbers and sizes of fires: long-term spatially explicit fire history in a Swedish boreal landscape. Ecology 81, 1484-1499. doi:10.1890/0012-9658(2000)081[1484:NASOFL]2.0.CO;2

Nunes MCS, Vasconcelos MJ, Pereira JMC, Dasgupta N, Alldredge RJ (2005) Land cover type and fire in Portugal: do fires burn land cover selectively? Landscape Ecology 20, 661-673. doi:10.1007/S10980-0050070-8

Pausas JG (2004) Changes in fire and climate in the eastern Iberian Peninsula (Mediterranean basin). Climatic Change 63, 337-350. doi:10.1023/ B:CLIM.0000018508.94901.9C

Pausas JG, Llovet J, Rodrigo A, Vallejo R (2008) Are wildfires a disaster in the Mediterranean basin? - A review. International Journal of Wildland Fire 17, 713-723. doi:10.1071/WF07151

Podur JJ, Martell DL (2009) The influence of weather and fuel type on the fuel composition of the area burned by forest fires in Ontario, 19962006. Ecological Applications 19, 1246-1252. doi:10.1890/08-0790.1

Rivas-Martínez S (1987) 'Mapa de las Series de Vegetación de España (1:400 000).' (Publicaciones del Ministerio de Agricultura, Pesca y Alimentación, Instituto Nacional para la Conservación de la Naturaleza: Madrid)

Romero-Calcerrada R, Perry GLW (2004) The role of land abandonment in landscape dynamics in the SPA 'Encinares del rio Alberche y Cofio', central Spain, 1984-1999. Landscape and Urban Planning 66, 217-232. doi:10.1016/S0169-2046(03)00112-9

Romero-Calcerrada R, Novillo CJ, Millington JDA, Gómez-Jiménez I (2008) GIS analysis of spatial patterns of human-caused wildfire ignition risk in the SW of Madrid (central Spain). Landscape Ecology 23, 341-354. doi:10.1007/S10980-008-9190-2

Savage RE (1931) The relation between the feeding of the herring off the east coast of England and the plankton of the surrounding waters. Fishery Investigation, Ministry of Agriculture, Food and Fisheries, Series 212 , $1-88$

Stephens SL (2005) Forest fire causes and extent on United States Forest Service lands. International Journal of Wildland Fire 14, 213-222. doi:10.1071/WF04006

Syphard AD, Radeloff VC, Keuler NS, Taylor RS, Hawbaker TJ, Stewart SI, Clayton MK (2008) Predicting spatial patterns of fire on a southern California landscape. International Journal of Wildland Fire 17, 602-613. doi:10.1071/WF07087

Syphard AD, Radeloff VC, Hawbaker TJ, Stewart SI (2009) Conservation threats due to human-caused increases in fire frequency in Mediterranean-climate ecosystems. Conservation Biology 23, 758-769. doi:10.1111/J.1523-1739.2009.01223.X

Turner MG, Romme WH, Gardner RH, Hargrove WW (1997) Effects of fire size and pattern on early succession in Yellowstone National Park. Ecological Monographs 67, 411-433. doi:10.1890/0012-9615(1997) 067[0411:EOFSAP]2.0.CO;2

Vasconcelos MJP, Silva S, Tome M, Alvim M, Pereira JMC (2001) Spatial prediction of fire ignition probabilities: comparing logistic regression and neural networks. Photogrammetric Engineering and Remote Sensing 67, 73-81

Vázquez A, Moreno JM (2001) Spatial distribution of forest fires in Sierra de Gredos (central Spain). Forest Ecology and Management 147, 55-65. doi:10.1016/S0378-1127(00)00436-9 
Viedma O, Moreno JM, Rieiro I (2006) Interactions between land use/land cover change, forest fires and landscape structure in Sierra de Gredos (central Spain). Environmental Conservation 33, 212-222. doi:10.1017/ S0376892906003122

Viedma O, Angeler DG, Moreno JM (2009) Landscape structural features control fire size in Mediterranean forested area of central Spain. International Journal of Wildland Fire 18, 575-583. doi:10.1071/ WF08030

Vilà M, Lloret F, Ogheri E, Terradas J (2001) Positive fire-grass feedback in Mediterranean Basin woodlands. Forest Ecology and Management 147, 3-14. doi:10.1016/S0378-1127(00)00435-7
Westerling AL, Hidalgo HG, Cayan DR, Swetnam TW (2006) Warming and earlier spring increase western US forest wildfire activity. Science 313, 940-943. doi:10.1126/SCIENCE.1128834

Wilson SF, Shackelton DM, Campbell KL (1998) Making habitat-availability estimates spatially explicit. Wildlife Society Bulletin 26, 626-631

Wittenberg L, Malkinson D (2009) Spatio-temporal perspectives of forest fires regimes in a maturing Mediterranean mixed pine landscape. European Journal of Forest Research 128, 297-304. doi:10.1007/ S10342-009-0265-7

Manuscript received 12 January 2010, accepted 2 December 2010 